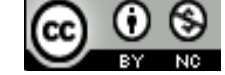

Jurnal Bimbingan Konseling Indonesia is licensed under

A Creative Commons Attribution-Non Commercial 4.0 International License.

\title{
KINERJA GURU BIMBINGAN DAN KONSELING SMA KOTA SURABAYA DAN FAKTOR-FAKTOR YANG MEMPENGARUHINYA
}

\author{
Mokhamad Imron ${ }^{1)}$, Najlatun Naqiyah ${ }^{2)}$, Retno Tri Hastuti ${ }^{3)}$ \\ ${ }^{1)}$ Prodi Bimbingan Konseling Pascasarjana Universitas Negeri Surabaya, Indonesia \\ E-mail: mokhamad.17071325005@mhs.unesa.ac.id \\ ${ }^{2)}$ Prodi Bimbingan Konseling Pascasarjana Universitas Negeri Surabaya, Indonesia \\ E-mail: najlatunnaqiyah@unesa.ac.id \\ ${ }^{3)}$ Prodi Bimbingan Konseling Pascasarjana Universitas Negeri Surabaya, Indonesia \\ E-mail: retnotri@unesa.ac.id
}

\begin{abstract}
Abstrak. Penelitian ini bertujuan untuk mendeskripsikan: (1) kinerja guru BK, pembinaan kepala sekolah, pembinaan pengawas, imbal jasa, dan pengalaman diklat guru BK SMA Kota Surabaya tahun pelajaran 2019-2020; (2) signifikansi pengaruh pembinaan kepala sekolah, pembinaan pengawas, imbal jasa, dan pengalaman diklat baik secara simultan maupun secara parsial terhadap kinerja guru BK. Penelitian ini menggunakan pendekatan kuantitatif jenis deskriptif eksplanatoris. Populasi guru BK SMA Kota Surabaya sejumlah 256 orang. Sampel 154 orang diambil menggunakan tabel Krejcie \& Morgan. Data dikumpulkan dengan kuesioner, dianalisis dengan statistik deskriptif dan regresi berganda. Hasil penelitian menunjukkan: (1) Secara deskriptif kinerja guru BK SMA Kota Surabaya tergolong baik, pembinaan kepala sekolah terhadap guru BK tergolong baik, pembinaan pengawas baik, pemberian imbal jasa tergolong baik, dan pengalaman diklat guru BK tergolong baik; (2) Pembinaan kepala sekolah, pembinaan pengawas, pemberian imbal jasa, dan pengalaman diklat secara simultan berpengaruh signifikan terhadap kinerja guru BK. $\mathrm{F}=164,9$ dan sig $\mathrm{p}<0.01$. Sumbangan efektifnya 83.2\%; (3) Secara parsial pembinaan kepala sekolah berpengaruh signifikan terhadap kinerja guru BK., sumbangan efektifnya 87\%; (4) Pembinaan pengawas berpengaruh signifikan terhadap kinerja guru BK., sumbangan efektifnya 27.2\%; (5) Pemberian imbal jasa berpengaruh signifikan terhadap kinerja guru BK., sumbangan efektifnya 11.5\%; (6) Pengalaman diklat berpengaruh signifikan terhadap kinerja guru BK., sumbangan efektifnya $24.6 \%$.
\end{abstract}

Kata Kunci: Kinerja guru bimbingan dan konseling; pembinaan kepala sekolah; pembinaan pengawas; imbal jasa; pengalaman diklat

\section{PENDAHULUAN}

Kinerja guru BK sering menjadi sorotan guru bidang studi. Guru BK diharapkan dapat menjadi solusi bagi permasalahan yang muncul di sekolah, khususnya dalam pencapaian prestasi belajar peserta didik. Begitu pula di dalam proses pembelajarannya di kelas, guru bidang studi berharap guru BK dapat membantu menyelesaikan permasalahan siswa dapat merasa mudah dalam mengikuti pembelajaran di kelas.
Guru BK di sekolah dituntut untuk berkinerja yang dapat memenuhi kebutuhan siswa dalam merencanakan karirnya, memecah-kan masalahmasalah belajar, masalah sosial maupun masalah pribadinya. Bimbingan dan konseling merupakan upaya yang sistematis, objektif, logis, dan berkelanjutan serta terprogram yang dilakukan oleh konselor atau guru BK dalam memfasilitasi perkembangan peserta didik/konseli untuk mencapai kemandirian dalam kehidupannya (Permenddikbud No. 111 Tahun 2014). 
Dalam Undang-undang Sisdiknas, peserta didik memiliki hak memperoleh pendidikan yang sepadan dengan potensi dirinya, baik bakat, minat, maupun kemampuannya (UU No. 20 Tahun 2003). Untuk itu peranan guru BK sangat diperlukan dalam mengembangkan bakat, minat dan potensi siswa. Amanat UU tersebut menuntut sekolah harus mampu memahami diri siswa, baik bakat, minat, maupun kemampuanya.

Berbekal pemahaman bakat, minat dan kemampuan riil siswa itulah sekolah dapat membantu siswa dalam merencanakan karirnya secara tepat. Berbekal pengetahuan tentang diri siswa tersebut sekolah dapat menempatkan siswa dalam program studi secara tepat, baik IPA, IPS ataupun bahasa. Juga dapat menempatkan lulusan ke studi lanjutan secara tepat melalui placement service program (layanan penempatan). Tugastugas tersebut itulah yang seharusnya menjadi tugas utama guru BK di SMA, sebab untuk itu diperlukan keahlian khusus, di antaranya keahlian melakukan pemeriksaan psikologis siswa (tes psikologis), proses bimbingan dan konseling individual serta kelompok. Tugas-tugas tersebut kurang layak jika diberikan kepada guru bidang studi sebab mereka memang tidak dipersiapkan untuk itu.

Dalam sistem pendidikan nasional, bimbingan merupakan bagian yang tidak dapat dipisahkan dari sistem pendidikanndi sekolah. Oleh karena itu tujuan BK mengacu pada pencapaian tujuan pendidikan nasional yang esensinya turut mengembangkan secara maksimal potensi peserta didik agar mereka dapat menjadi manusia beriman dan bertaqwa terhadap Tuhan, mamiliki akhlak mulia, sehat jasmani dan rohani, memiliki ilmu yang memadai, cakap, kreatif, memiliki kemandirian, demokratis, serta bertanggungjawab. Bimbingan adalah salah satu kegiatan pendidikan, di samping pengajaran dan latihan, ketiga kegiatan ini tidak dapat dipisahkan karena ketiganya mempunyai sasaran yang sama, yaitu mewujudkan tujuan pendidikan. Akan tetapi dari ketiga kegiatan tersebut berbeda dalam penanganan dan tekniknya. Jika bimbingan dan konseling lebih bersifat informal dan personal, pengajaran dan latihan bersifat formal dan struktural. Bimbingan pada prinsipnya merupakan bentuk bantuan kepada siswa dengan maksud menemukan potensi dirinya, mengenal lingkungan dan merenca-nakan masa depannya (PP No. 29 Tahun 1990).

Eksistensi guru BK tidak dapat dipisahkan dari eksistensi guru pada umumnya. Oleh karena itu kajian tentang guru dalam sistem pendidikan nasional juga menyangkut guru BK. Sebagai pendidik professional, guru memiliki tugas pokok mendidik, juga mengajar serta membimbing, melatih, mengarahkan dan mengevaluasi peserta didik, baik pada pendidikan: anak usia dini, pendidikan dasar dan pendidikan menengah (UU No. 14 Tahun 2005). Berdasarkan tugas dan kedudukan guru tersebut, jelaslah bahwa eksistensi guru saat ini sangat prospektif bagi kemajuan pendidikan nasional, bergantung bagimana kreativitas guru dalam meningkatkan profesionalisme dirinya, termasuk guru BK.

Guru, termasuk guru BK, sebagai salah satu input sekolah di SMA sudah barang tentu dalam mengelola program bimbingan dan konselingnya dipengaruhi oleh berbagai faktor, di antaranya: 1) pembinaan (supervisi) kepalassekolah; 2) pembinaan pengawas; 3) kompensasi (imbal jasa); dan 4) pengalaman mengikuti pendidikan serta pelatihan (diklat), termasuk tingkat pendidikan dan berbagai pengalaman mengikuti pelatihan peningkatan profesi sebagai guru BK, serta faktorfaktor lainnya.

Pengaruh pembinaan kepala sekolah terhadap kinerja guru telah banyak diteliti, di antaranya Ramadona dan Wibowo (2016) yang menemukan bahwa pembinaan kepala sekolah berpengaruh signifikan dan positif terhadap performansi guru, dimana $49,63 \%$ performansi guru merupakan kontribusi pembinaan kepala sekolah. Chidi \& Victor (2017) menemukan bahwa ada korelasi positif yang tinggi antara teknik pembinaan kepala sekolah dengan observasi kelas dan performansi guru. Selain itu ada hubungan yang signifikan antara teknik supervisi demonstrasi kepala sekolah dan performansi guru. Beberapa hasil studi tersebut membuktikan bahwa supervisi kepala sekolah dapat meningkatkan kinerja atau performansi guru. Oleh karena itu dalam studi ini hubungan kedua variabel tersebut juga dikaji dalam konteks kinerja guru BK SMA Kota Surabaya. 
Kinerja guru BK dapat dipengaruhi juga oleh pembinaan pengawas guru BK. Tugas pengawas adalah melaksanakann pengawasan akademik dan manajerial pada satuan pendidikan yang meliputi penyusunan program pengawasan, pelaksanaan pembinaan, pemantauan pelaksanaan delapan Standar Nasional Pendidikan, penilaian, pembimbingan dan pelatihan profesional guru, evaluasi hasil pelaksanaann pengawasan, dan pelaksanaan tugas kepengawasann di daerah khusus (Permen PAN \& Reformasi Birokrasi No. 21 Tahun 2010). Temuan penelitian (Poernamawijaya dkk, 2018) menunjukkan bahwa ada kontribusi langsung pembinaan pengawas terhadap kinerja guru. Ramadhan, (2017) juga menemukan bahwa supervisi akademik pengawas sekolah berkontribusi signifikan terhadap performansi guru.

Faktor lain yang juga dapat mempengaruhi kinerja guru dalam pengeloaan program BK adalah imbal jasa. Kesesuaian jumlah imbal jasa finansial seperti gaji, insentif dan berbagai tunjangan dengan harapan guru $\mathrm{BK}$ dan ketepatan serta kemudahan cara penerimaannya tentunya akan memberikan motivasi kerja bagi guru BK yang dampaknya dapat dirasakan pada membaiknya kinerja mereka dalam pengelolaan program BK. Demikian juga dalam pemberian imbal jasa nonfinansial, seperti promosi, kesempatan mengembangkan diri, dan lingkungan kerja yang kondusif.

Pemberian imbal jasa ini menurut Fray (Herpen dkk, 2002) disebut pemotivasian ekstrinsik, adalah motivasi yang diperoleh dengan pengkondisian faktor-faktor eksternal yang dapat mempengaruhi kebutuhan kepuasan seperti pemberian stimulasi insentif uang. Pemberian imbal jasa kepada guru BK di SMA se Kota Surabaya secara finansial dirasakan guru-guru BK sudah memadai, terlebih dengan kebijakan sertifikasi bagi guru.

Pengaruh imbal jasa atau kompensasi terhadap performansi telah banyak diuji. Suryantoro, dkk. (2018) menemukan bahwa ada pengaruh signifikan imbal jasa terhadap motivasi kerjaagguru di tempat kerja. Widayati, (2019) juga menemukan efek positif antara imbal jasa dan performansi guru. Pengaruh pemberian kompensasi terhadap kinerja guru adalah $=0,493$, berarti $49,3 \%$ kinerja guru merupakan kontribusi kompensasi. Beberapa temuan penelitian tersebut memperkuat hubungan antara imbal jasa dengan kinerja guru.

Tingkat pendidikan guru BK juga dapat mempengaruhi kinerja guru BK dalam mengelola program BK, semakin tinggi tingkat pendidikan guru semakin potensial prestasi kerjanya meningkat karena bertambahnya pengetahuan dan pengalaman dalam mengelola program BK. Secara logis hubungan tingkat pendidikan dengan kinerja guru BK menunjukkan hubungan linear, yang berarti bahwa semakin tinggi tingkat pendidikan guru BK, akan semakin tinggi pula performansi manajerialnya dalam mengelola program $\mathrm{BK}$, demikian juga berbagai pengalaman diklat atau pelatihan profesional yang pernah diikutinya (Turin, 2002).

Rahman, dkk. (2011) menemukan bahwa pelatihan guru berhubungan positif dengan pengajaran yang efektif. Ataunur dan Ariyanto (2015) menemukan bahwa secara bersamaan, kompetensi dan pelatihan berpengaruh dominan positif ssignifikan terhadap kinerja karyawan, koefisien determinasi sebesar $73.6 \%$. Hervie, dkk. (2018) mengungkapkan bahwa kinerja guru yang buruk disebabkan oleh kurang seringnya mengikuti pelatihan dalam jabatan, kurangnya bahan pengajaran dan pembelajaran, kurangnya insentif dan motivasi, dan pengawasan yang tidak tepat.

Temuan ini dapat diartikan bahwa salah satu penyebab rendahnya kinerja guru adalah kurangnya mengikuti pelatihan. Beberapa temuan penelitian tersebut memperkuat bahwa pengalaman diklat berkontribusi terhadap kinerja guru. Hubungan antara beberapa variabel bebas tersebut dengan kinerja guru mendorong dilakukan studi ini dalam konteks kinerja guru BK SMA di Kota Surabaya.

\section{METODE}

Jenis penelitian ini deskriptif eksplanatoris, penelitiannyyang berusaha menjelaskan hubungan kausal yang terjadi antara variabel-variabel penelitian dan menguji hipotesis yang telah dirumuskan. Dalam penelitian eksplanatories perubahan pada variabel tertentu menyebabkan timbulnya suatu akibat tertentu atas variabel kedua (Winardi, 2001). Populasi keseluruhan guru BK SMA Kota Surabaya sejumlah 256 orang. Sampel 
diambil sebanyak 154 orang menggunakan tabel sampling Krejcie \& Morgan. Data dikumpulkan dengan kuesioner, dianalisis dengan statistik deskriptif dan regresi berganda.

\section{HASIL DAN PEMBAHASAN}

HASIL

TABEL 1

KINERJA GURU BK

\begin{tabular}{|l|l|}
\hline Sub Variabel & $\begin{array}{l}\text { Nilai dan } \\
\text { Kualifikasi }\end{array}$ \\
\hline $\begin{array}{l}\text { Kinerja dalam pemberi-an layanan dasar } \\
\text { BK }\end{array}$ & 4.17 (Sangat Baik) \\
\hline $\begin{array}{l}\text { Kinerja dalam pemberian layanan } \\
\text { peminatan dan perencanaan individual }\end{array}$ & 3.33 (Baik) \\
\hline Kinerja dalam layanan responsif & 3.00 (Baik) \\
\hline $\begin{array}{l}\text { Kinerja dalam meningkatkan dukungan } \\
\text { sistem }\end{array}$ & 3.11 (Baik) \\
\hline Rerata Nilai dan Kualifikasi Variabel & $\mathbf{3 . 4 0}$ (Baik) \\
\hline
\end{tabular}

Tabel 1 menjelaskan: (1) kinerja guru BK dalam pengelolaan program BK secara umum tergolong "baik", rerata nilai 3.40; (2) kinerja guru BK dalam pemberian layanan dasar BK tergolong "sangat baik", rerata nilai 4.17; (3) Kinerja guru BK dalam layanan responsif tergolong "baik", rerata nilai 3.00; dan (4) kinerja guru BK dalam meningkatkan dukungan sistem tergolong "baik", rerata nilai 3.11.

TABEL 2

PembinaAn KePala Sekolah KePada GuRu BK

\begin{tabular}{|l|l|}
\hline Sub Variabel & $\begin{array}{l}\text { Nilai dan } \\
\text { Kualifikasi }\end{array}$ \\
\hline Pembinaan Teknis BK & 3.04 (Baik) \\
\hline $\begin{array}{l}\text { Pembinaan dalam pemberian layanan dasar } \\
\text { BK }\end{array}$ & 3.17 (Baik) \\
\hline $\begin{array}{l}\text { Pembinaan dalam pemberian layanan } \\
\text { peminatan dan perencanaan individual }\end{array}$ & 3.40 (Baik) \\
\hline Pembinaan dalam layanan responsif & 2.81 (Kurang Baik) \\
\hline $\begin{array}{l}\text { Pembinaan dalam meningkatkan dukungan } \\
\text { sistem }\end{array}$ & 2.76 (Kurang baik) \\
\hline Pembinaan Non Teknis BK & 3.30 (Baik) \\
\hline Rata-rata nilai dan kualifi-kasi variabel & $\mathbf{3 . 2 1}$ (Baik) \\
\hline
\end{tabular}

Tabel 2 menjelaskan: (1) pembinaan kepala sekolah kepada guru BK tergolong "baik", rerata nilai 3.21 ; (2) pembinaan pada aspek teknis, tergolong "baik", rerata nilai 3.04 dengan rincian pembinaan pada aspek layanan dasar BK dan dalam pemberian layanan peminatan dan perencanaan individual tergolong baik dengan rerata nilai 3.00/>, sedangkan pembinaan dalam layanan responsif dan dalam meningkatkan dukungan sistem tergolong "kurang baik" dengan rerata nilai < 3.00; (3) pembinaan pada aspek non teknis tergolong "baik", dengan rerata nilai 3.21 .

TABEL 3

PEMBINAAN PENGAWAS

\begin{tabular}{|l|l|}
\hline Sub Variabel & $\begin{array}{l}\text { Nilai dan } \\
\text { Kualifikasi }\end{array}$ \\
\hline Pembinaan Teknis BK & 3.08 (Baik) \\
\hline $\begin{array}{l}\text { Pembinaan dalam pemberian layanan dasar } \\
\text { BK }\end{array}$ & $\begin{array}{l}2.81 \text { (Kurang } \\
\text { Baik) }\end{array}$ \\
\hline $\begin{array}{l}\text { Pembinaan dalam pemberian layanan } \\
\text { peminatan dan perencanaan individual }\end{array}$ & 3.18 (Baik) \\
\hline Pembinaan dalam layanan responsif & 3.18 (Baik) \\
\hline $\begin{array}{l}\text { Pembinaan dalam meningkatkan dukungan } \\
\text { sistem }\end{array}$ & 3.36 (Baik) \\
\hline $\begin{array}{l}\text { Pembinaan Non Teknis BK } \\
\text { Rata-rata nilai dan kualifikasi variabel } \\
\text { Pembinaan Pengawas }\end{array}$ & $\mathbf{3 . 2 0}$ (Baik) \\
\hline
\end{tabular}

Tabel 3 menjelaskan: (1) pembinaan pengawas kepada guru BK tergolong "baik", rerata nilai 3.20; (2) pembinaan pada aspek teknis "baik", rerata nilai 3.07, dengan rincian pembinaan pada aspek layanan dasar BK "kurang baik", rerata nilai 2.81, sedangkan pemberian layanan peminatan dan perencanaan individual, pembinaan dalam layanan responsif, dan pembinaan dalam meningkatkan dukungan sistem tergolong "baik" dengan rerata nilai > 3.00; (3) pembinaan pada aspek non teknis tergolong "baik", rerata nilai 3.33.

TABEL 4

IMBAL JASA GURU BK

\begin{tabular}{|l|l|}
\hline Sub Variabel & Nilai dan Kualifikasi \\
\hline Gaji & 3.01 (Baik) \\
\hline Insentif & 2.88 (kurang baik) \\
\hline Tunjangan & 3.22 (Baik) \\
\hline Promosi & 2.83 (Kurang Baik) \\
\hline Pengembangan Diri & 2.09 (Kurang Baik) \\
\hline Dukungan Lingkungan Kerja & 3.29 (Baik) \\
\hline $\begin{array}{l}\text { Rata-rata nilai dan kualifikasi } \\
\text { variabel Imbal Jasa }\end{array}$ & $\mathbf{3 . 0 3}$ (Baik) \\
\hline
\end{tabular}

Tabel 4 menjelaskan bahwa imbal jasa kepada guru BK termasuk "Baik", rerata nilai 3.03, rinciannya: pemberian gaji "Baik" $(3,01)$, insentif "Kurang Baik" (2,88), tunjangan "Baik", $(3,22)$ promosi "Kurang Baik", $(2,83)$ pengembangan diri 
"Kurang Baik" 2,09, dan dukungan lingkungan kerja "Baik" $(3,29)$.

TABEL 5

PENGALAMAN GURU BK

\begin{tabular}{|l|l|}
\hline Sub Variabel & $\begin{array}{l}\text { Nilai dan } \\
\text { Kualifikasi }\end{array}$ \\
\hline Tingkat pendidikan guru BK & $\mathbf{3 . 6 0}$ (Baik) \\
\hline Frekuensi mengikuti diklat & $\mathbf{3 . 5 2}$ (Baik) \\
\hline Analisis kebutuhan diklat & $\mathbf{3 . 6 7}$ (Baik) \\
\hline Kesesuaian diklat dengan kebutuhan guru BK & $\mathbf{3 . 4 0}$ (Baik) \\
\hline $\begin{array}{l}\text { Efektivitas diklat dalam meningkatkan } \\
\text { profesionalisme }\end{array}$ & $\mathbf{3 . 6 7}$ (Baik) \\
\hline $\begin{array}{l}\text { Manfaat diklat dalam menunjang kinerja guru } \\
\text { BK }\end{array}$ & $\mathbf{3 . 5 2}$ (Baik) \\
\hline $\begin{array}{l}\text { Rata-rata nilai dan kualifikasi variabel } \\
\text { Pengalaman Diklat }\end{array}$ & (Baik) \\
\hline
\end{tabular}

Tabel 5 menjelaskan bahwa penga-laman diklat guru BK tergolong "Baik" $(3,56)$, rinciannya: (1) tingkat pendidikan guru BK "Baik" $(3,50)$, Frekuensi mengikuti diklat "Baik" $(3,52)$, analisis kebutuhan diklat "Baik" $(3,67)$, kesesuaian diklat dengan kebutuhan guru BK "Baik" $(3,40)$, efektivitas diklat dalam meningkatkan profesionalisme "Baik" $(3,67)$, dan manfaat diklat dalam menunjang kinerja guru BK juga tergolong "Baik" (3,53).

TABEL 6

HASIL UJI HIPOTESIS

\begin{tabular}{|l|l|l|l|l|l|}
\hline Variabel & B & Beta & $\begin{array}{l}\text { Sig t } \\
(\mathbf{p})\end{array}$ & $\boldsymbol{\alpha}$ & Keputusan \\
\hline $\begin{array}{l}\text { Pembinaan } \\
\text { kep.sekolah (X1) }\end{array}$ & .628 & .870 & .000 & .05 & Ho Ditolak \\
\hline $\begin{array}{l}\text { Pembinaan } \\
\text { pengawas (X2) }\end{array}$ & .177 & .272 & .025 & .05 & Ho Ditolak \\
\hline Imbal jasa (X3) & .144 & .115 & .000 & .05 & Ho Ditolak \\
\hline $\begin{array}{l}\text { Pengalaman diklat } \\
(X 4)\end{array}$ & .747 & .246 & .000 & .05 & Ho Ditolak \\
\hline $\begin{array}{l}\text { Constanta }=\mathbf{- 8 . 3 3 6} \\
\text { Multiple R = .912 } \\
\text { R Square = .832 } \\
\text { F }=\mathbf{1 8 4 . 9 2 8}\end{array}$ & & $\alpha=.05$ & \\
\hline
\end{tabular}

Berdasarkan tabel 6 dapat dijelaskan sebagai berikut:

1) Hasil uji $F$ (uji simultan) menunjukkan bahwa $\mathrm{F}=184.928$ dan $\mathrm{p}=0.000<0.050$, yang berarti peluang salah $<\alpha 0.050$. Oleh karena itu dapat disimpulkan bahwa $\mathrm{H}_{\mathrm{o}}$ "pembinaan kepala sekolah, pembinaan pengawas, imbal jasa, dan pengalaman diklat secara bersama-sama tidak berpengaruh signifikan terhadap kinerja guru BK" ditolak. Hal ini berarti makin tinggi nilai variabel pembinaan kepala sekolah $\left(\mathrm{X}_{1}\right)$, pembinaan pengawas $\left(\mathrm{X}_{2}\right)$, imbal jasa $\left(X_{3}\right)$, dan pengalaman diklat $\left(X_{4}\right)$ secara bersama-sama menyebabkan makin tingginya kinerja guru BK dalam pengelolaan pembelajaran (Y), demikian sebaliknya. Koefisien determinasi berganda yang merupakan efektivitas garis regresi $\left(\mathrm{R}^{2}\right)$ sebesar .832, dapat diartikan bahwa $83.2 \%$ kinerja guru $\mathrm{BK}$ ditentukan oleh pembinaan kepala sekolah, pembinaan pengawas, imbal jasa, dan pengalaman diklat. Sisanya, sebesar $14.8 \%$ merupakan pengaruh variabel lain yang tidak diteliti.

2) Koefisien arah regresi terbaku antara variabel pembinaan kepala sekolah dengan kinerja guru $\mathrm{BK}=.628$, signifikansi $\mathrm{t}$ $=.000 . \mathrm{H}_{0} \mathrm{X}_{1}$ ditolak. Beta $\mathrm{X}_{1} \mathrm{y}=.870$, berarti sumbangan efektif pembinaan kepala sekolah terhadap kinerja guru BK sebesar $87 \%$, artinya $13 \%$ kinerja guru BK dapat dijelaskan karena pembinaan kepala sekolah dengan asumsi variabel lain dianggap konstan.

3) Koefisien arah regresi terbaku antara variabel pembinaan pengawas dengan kinerja guru $\mathrm{BK}=.177$, signifikansi $\mathrm{t}=$ $0.000>0.05, \mathrm{H}_{0} \mathrm{X}_{2}$ ditolak. Hal itu berarti jika pembinaan pengawas ditingkatkan .177 simpangan baku, maka nilai kinerja guru BK akan meningkat sebesar .177 simpangan baku. Beta $\mathrm{X}_{2} \mathrm{y}=.272$, berarti sumbangan efektifnya $27 \%$, artinya $27 \%$ kinerja guru BK dapat dijelaskan karena pembinaan pengawas dengan asumsi variabel lain dianggap konstan.

4) Koefisien arah regresi terbaku antara variabel pemberian imbal jasa dengan kinerja guru $\mathrm{BK}=.144$, signifikansi $\mathrm{t}$ $=.028$. tingkat kesalahan $\mathrm{t}$ hitung $\leq \alpha 0.05$. Oleh karena itu hipotesis nihil $\left(\mathrm{H}_{0} \mathrm{X}_{3}\right)$ ditolak. Beta $\mathrm{x}_{3} \mathrm{y}=0.115$, hal itu berarti sumbangan efektifnya $11.5 \%$, artinya $11.5 \%$ kinerja guru BK dapat dijelaskan karena 
pemberian imbal jasa dengan asumsi variabel lain dianggap konstan.

5) Koefisien arah regresi terbaku antara variabel pengalaman diklat guru dengan kinerja guru $\mathrm{BK}=.747$, signifikansi $\mathrm{t}$ $=.000$, tingkat kesalahan $\mathrm{t}$ hitung $<\alpha 0.01$. Oleh karena itu $\mathrm{H}_{0} \mathrm{X}_{4}$ ditolak. Beta $\mathrm{x}_{4} \mathrm{y}$ $=.246$, hal itu berarti sumbangan efektifnya $24.6 \%$, artinya $24.6 \%$ kinerja guru BK dapat dijelaskan karena pengalaman diklat guru BK dengan asumsi variabel lain dianggap konstan. Berdasarkan pengujian hipotesis parsial tersebut, jelaslah bahwa sumbangan efektif terbesar adalah variabel pembinaan kepala sekolah kepada guru BK, yakni $87 \%$, urutan berikutnya adalah pengalaman diklat (24.6\%), kemudian pembinaan pengawas (22.7\%), dan terkecil imbal jasa (11.5\%).

\section{PEMBAHASAN}

Temuan penelitian menunjuk-kan bahwa pembinaan kepala sekolah kepada guru BK, pembinaan pengawas, pemberian imbal jasa, dan pengalaman diklat secara bersama-sama berpengaruh positif signifikan terhadap kinerja guru BK. F = 184.928 dan sig $\mathrm{p}<0.01$. Sumbangan efektif sebesar $83.2 \%$, berarti $83.2 \%$ kinerja guru BK ditentukan secara bersama-sama oleh pembinaan kepala sekolah, pembinaan pengawas, pemberian imbal jasa, dan pengalaman diklat guru BK. Sisanya, sebesar $16.8 \%$ merupakan pengaruh variabel lain yang tidak diteliti.

Secara parsial, ternyata pembinaan kepala sekolah kepada guru BK berpengaruh signifikan terhadap kinerja guru, sumbangan efektifnya sebesar $87 \%$, artinya $87 \%$ kinerja guru BK dapat dijelaskan karena pembinaan kepala sekolah dengan asumsi variabel lain dianggap konstan. Temuan penelitian ini sejalan dengan pendapat Mulyasa (2005) yang menyatakan bahwa kepala sekolah merupakan salah satu komponen pendidikan yang paling berperan dalam meningkatkan kualitas pendidikan, termasuk kualitas guru BK. Oleh karena itu pembinaan kepala sekolah akan lebih diperhatikan guru BK dibanding dengan pembinaan yang dilakukan oleh pihak lain, termasuk pengawas, sebab kepala sekolahlah yang memiliki wewenang untuk mempromosikan dan memutasi guru BK.

Temuan penelitian ini juga sejalan dengan temuan Siregar (2018) yang menemukan bahwa kepemimpinan kepalas sekolah berpengaruh signifikan terhadapkkinerja guru BK. Juga sejalan dengan temuan Ramadona dan Wibowo (2016) yang menemukan bahwa supervisikkepala sekolah berpengaruh signifikan dan positif terhadap kinerja guru. Yousaf et al. (2018) juga menguatkan temuan penelitian ini, mereka menemukan bahwa praktik pengawasan kepala sekolah yang terkait dengan pengembangan staf memang membantu dalam mencapai kinerja guru yang lebih baik dan pertumbuhan mereka secara keseluruhan. Temuan penelitian Renata, dkk. (2018) juga memperkuat temuan penelitian ini, mereka menemukan bahwa ada pengaruh yang signifikan dari pengawasan kepala sekolah terhadap guru yang efektif.

Temuan penelitian menunjuk-kan bahwa secara parsial pembinaan pengawas berpengaruh signifikan terhadap kinerja guru BK. Sumbangan efektifnya terhadap kinerja guru BK sebesar $27.2 \%$. Temuan penelitian ini sejalan dengan pendapat menurut Mulyasa (2005) bahwa pengawas memiliki peran yang penting bagi upaya meningkatkan profesionalisme kinerja kepala sekolah dan stafnya, termasuk guru BK. Temuan penelitian ini sejalan dengan temuan Ramadhan (2017) yang menemukan: (1) kompetensi supervisi akademik pengawas sekolah berpengaruh signifikan terhadap kinerja guru, (2) supervisi kepala sekolah berpengaruh signifikan terhadap kinerja guru, (3) kompetensi supervisi akademik pengawas sekolah dan supervisi kepala sekolah secara bersama-sama berpengaruh signifikan terhadap kinerja guru.

Temuan penelitian menunjuk-kan bahwa pemberian imbal jasa secara parsial berpengaruh positif sigifikan terhadap kinerja guru BK. sumbangan efektifnya $11.5 \%$, artinya $11.5 \%$ kinerja guru BK dapat dijelaskan karena pemberian imbal jasa kepada guru BK dengan asumsi variabel lain dianggap konstan. Secara deskriptif pemberian imbal jasa kepada guru BK ini juga termasuk baik. Baiknya nilai pemberian imbal jasa kepada guru BK ini menunjukkan bahwa Dinas Pendidikan Kota Surabaya dan atau Yayasan Pendidikan SMA di 
Kota Surabaya telah memperhatikan prinsip-prinsip peningkatan kinerja guru sebagai pegawai sebagaimana dikemukakan para ahli. Griffin \& Moorhead (1986) mengemukakan bahwa ...To attain high levels of performance, an employee must want to do the job (motivation), be capable of doing the job (ability), and have the right materials and equipment (environmen). Hal itu dapat diartikan bahwa untuk memperoleh tingkat kinerja yang tinggi, seseorang pegawai harus memiliki keinginan untuk melakukan pekerjaan (motivation), mampu melakukan pekerjaan (ability), dan memiliki bahan serta perlengkapan yang benar (lingkungan).

Upaya meningkatkan pemberian imbal jasa pada dasarnya merupakan upaya meningkatkan motivasi kerja, sebab dengan imbal jasa yang memadai mengakibatkan kepuasan kerja bagi guru dan akan mempengaruhi pada membaiknya kinerja guru. Sebagaimana dikemukakan Boyett and Boyett (2002) ...Motivation for better performance depends on job satisfaction, achievement, recognition, and profesional growth. ...providing a positive motivasional work environment is a challenging managerial activity. Motivasi bagi peningkatan kinerja pegawai bergantung pada kepuasan kerja, prestasi, penghargaan dan pertumbuhan profesional pegawai. Pemberian lingkungan kerja yang positif bagi peningkatan motivasi kerja pegawai merupakan sebuah tantangan bagi aktivitas manajerial, termasuk dalam konteks penelitian ini merupakan tantangan bagi kepala sekolah, Kepala Dinas Pendidikan Kota Surabaya sebagai pemimpin pengelolaan pendidikan di Kota Surabaya. Pemberian imbal jasa merupakan salah satu lingkungan kerja, oleh karena itu apabila hal itu kondusif maka akan meningkatkan kepuasan kerja dan hal itu berarti meningkatkan motivasi kerja guru. Motivasi kerja akan berpengaruh pada kinerja, demikian dengan pemberian imbal jasa kepada guru BK.

Temuan penelitian ini juga sejalan dengan temuan Hewitt (Hansen, 2006) yang menemukan bahwa $79 \%$ perusahaan yakin bahwa program pemberian upah dapat membantu meningkatkan hasil bisnis mereka, 21\% mengatakan bahwa program pemberian upah mereka tidak berpengaruh terhadap hasil mereka, sebagaimana dikemukakan ...Hewitt's study also revealed that $79 \%$ of companies believe variable pay programs help improve their business results, whereas $21 \%$ say that they have no effect on their results.

Walaupun program pemberian imbal jasa (kompensasi) dapat meningkatkan kinerja guru sebagaimana temuan penelitian ini, namun efektivitas penyusunan program kompensasi harus didasarkan atas hubungan antara kinerja mereka dengan kompensasi atau hadiah yang potensial. Jadi untuk mengoptimalkan kinerja tertentu harus dirancang dengan kebijakan pemberian kompensasi tertentu pula. Penyampaian program pemberian kompensasi memang perlu dilakukan, namun itu saja tidak cukup.

Beberapa komponen perencanaan kinerja akan memiliki keterkaitan khusus terhadap kompensasi, dan hal itu perlu dipenuhi. Sebagaimana direkomendasikan oleh Summers (2005) ...For pay for performance to be effective, everyone needs to have a clear understanding of relationship between their performance and their potential reward. Communicating a compensation plan is necessary but not sufficient. Some components of the performance plan will have specific links to compensation, and they need to be spelled out. Temuan penelitian ini juga sejalan dengan temuan Pitri (2017) yang menemukan bahwaacsecara simultannkompensasi (imbal jasa) berpengaruh positif signifikan terhadap kinerjagguru. Yuddin (2017) juga menemukan bahwa kompensasi, motivasi dan disiplin kerja secara bersama berpengaruh signifikan dan positif terhadap kinerja guru.

Temuan penelitian menunjukkan bahwa pengalaman diklat berpengaruh signifikan terhadap kinerja guru BK, sumbangan efektifnya $24.5 \%$. Temuan penelitian ini menunjukkan bahwa semakin tinggi tingkat pendidikan guru dan semakin tinggi pengalaman mengikuti berbagai diklat profesi diikuti secara proporsional dengan semakin meningkatnya kinerja guru BK. Temuan ini menandakan bahwa untuk rekruetmen dan pemberdayaan guru diperlukan sistem seleksi yang mensyaratkan tingkat pendidikan kependidikan 
yang memadai dan pemberian diklat profesi yang mengacu pada kebutuhan guru.

Temuan penelitian ini sejalan dengan temuan Ataunur dan Ariyanto (2015) yang menemukan bahwa secara bersamaan kompetensi dan pelatihan berpengaruh positif signifikan secara dominan terhadap kinerja karyawan. Penelitian lainnya yang menemukan hal yang relatif sama dengan temuan penelitian ini adalah penelitian Turin (2002) yang menemukan: 1) Terdapat hubungan yang signifikan antara tingkat pendidikan guru dengan performansi mengajarnya; 2) Ada kontribusi (pengaruh) antara pengalaman penataran dengan performansi mengajar guru SMUN 3 Kendari; 3) Terdapat hubungan yang signifikan antara motivasi kerja dengan performansi mengajar; 4) Secara bersamasama terdapat hubungan yang signifikan antara tingkat pendidikan, pengalaman penataran dan motivasi kerja dengan performansi mengajar guru SMU Negeri 3 Kendari.

Kinerja guru merupakan hasil karya salah satu sumber daya sekolah, yakni guru, termasuk guru BK. Hal itu akan berkontribusi terhadap kinerja sekolah secara keseluruhan. Sebab majumundurnya sekolah sebagai organisasi bergantung pada sumber dayanya, termasuk guru BK. Christensen (2001) mengemukakan ... Resources are the most visible of the factors that contribute to what an organization can and cannot do. Sumber daya merupakan faktor yang paling terlihat yang berkontribusi terhadap bekerjatidaknya suatu organisasi. Atas dasar kajian tersebut kiranya layak untuk dikemukakan bahwa temuan penelitian ini memiliki kadar objektivitas yang cukup tinggi, sebab relevan dengan temuan penelitian terdahulu.

\section{KESIMPULAN}

Secara deskriptif kinerja guru BK SMA Kota Surabaya tergolong baik, pembinaan kepala sekolah terhadap guru BK tergolong baik, pembinaan pengawas baik, pemberian imbal jasa tergolong baik, dan pengalaman diklat guru BK tergolong baik.

Pembinaan kepala sekolah, pembinaan pengawas, pemberian imbal jasa, dan pengalaman diklat secara simultan berpengaruh signifikan terhadap kinerja guru BK. Pembinaan kepala sekolah secara parsial berpengaruh signifikan tergadap kinerja guru BK. Pembinaan pengawas secara parsial berpengaruh signifikan terhadap kinerja guru BK. Pemberian imbal jasa secara parsial berpengaruh signifikan terhadap kinerja guru BK. Pengalaman diklat secara parsial berpengaruh signifikan terhadap kinerja guru BK.

\section{DAFTAR PUSTAKA}

Ataunur, I. \& Ariyanto, E. (2015). Pengaruh Kompetensi dan Pelatihan Terhadap Kinerja Karyawan Pt Adaro Energy Tbk. Telaah Bisnis, 16(2).

Bessell I., Dicks B., Wysocki A., \& Kepner K., (2002). Understanding motivation: an effective tool for managers. University of Florida diakses dari http://Edis.ifas.ulf.edu pada tgl. 30 Mei 2019.

Chidi, N. \& Victor, A.A. (2017). Principals' Supervisory Techniques as Correlates of Teachers' Job Performance in Secondary Schools in Ebonyi State, Nigeria. International Journal for Social Studies, 3(10).

Cristensen, C. M. (2001). Assessing your organization's innovation capabilities. Leader to leader, (21).

Griffin, R. W. \& Moorhead, G. (1986). Organizational behavior. Boston: Houghton Mifflin Company

Hansen, F. (2006.) Currents in compen-sation and benefits. Compensation \& benefits review, 38(5), 6-21.

Herpen. M. V., Praag, M. V., Cools, K. (2002). The effects of performance measurement and compensation on motivation: An empirical study. Discussion Paper, 48(3).

Hervie, D.M. \& Winful, E.C. (2018). Hancing Teachers' Performance through Training and Development in Ghana Education Service (A Case Study of Ebenezer Senior High School) Journal of Human Resource Management.

Mulyasa, E., (2005). Menjadi kepala sekolah profesional dalam konteks menyukseskan MBS dan KBK. Bandung: PT Remaja Rosdakarya.

Peraturan Pemerintah No. 29 tahun 1990 tentang Pendidikan Menengah.

Permen PAN dan Reformasi Birokrasi no. 21 tahun 2010 tentang Jabatan Fungsional Pengawas dan Angka Kreditnya.

Permendikbud No. 111 tahun 2014 tentang Bimbingan dan Konseling pada Pendidikan Dasar dan Pendidikan Menengah.

Pitri, A. (2017). Pengaruh Kompensasi Terhadap Kinerja Guru Di SMP Negeri 3 Batusangkar. JMKSP Jurnal Manajemen, Kepemimpinan, dan Supervisi Pendidikan, 2(1).

Poernamawijaya, L.W.S., Sulaiman, Suriansyah, Ahmad, Dalle, Juhriyansyah. (2018). Contribution On Supervision of Supervisor, Principals Motivation, Kindergarten Teacher Performance To Improving The 
Kindergarten Quality In West Banjarmasin, Indonesia. European Journal Of Alternative Education Studies, 3(2). Rahman, Fazalur, Jumani, Nabi B., Headmistress, Yasmin Akhter. Chisthi, S.H, \& Ajmal, M. (2011). Relationship between Training of Teachers and Effectiveness Teaching. International Journal of Business and Social Science, 2(4).

Ramadhan, A. (2017). Pengaruh Pelaksanaan Supervisi Akademik Pengawas Sekolah dan Supervisi Kepala Sekolah Terhadap Kinerja Guru SMK Negeri di Kabupaten Majene. EST: Journal of Educational Science and Technology, 3(2).

Ramadona, M \& Wibowo, R. (2016). Pengaruh Supervisi Kepala Sekolah Terhadap Kinerja Guru Di SMP K 1 Penabur Pasar Baru Jakarta Pusat. Research and Development Journal of Education, 3(1).

Renata, Wardiah, Dessy, \& Kristiawan, M. (2018). The Influence Of Headmaster's Supervision And Achievement Motivation On Effective Teachers. International Journal of Scientific \& Technology Research, 7(6).

Siregar, Y. (2018). Pengaruh gaya kepemimpinan kepala sekolah terhadap kinerja guru bimbingan dan konseling di SMA Negeri Jakarta Timur. Teraputik. Jurnal Bimbingan dan Konseling, 1(3).

Summers, L. (2005). Integrated pay for performance: the high-tech marriage of compensation management and performance management. Compensation \& benefits review, 37(1), 18-25.

Suryantoro, Igor, Amin, Maswardi. M. \&, M. Chiar. (2018). The Effect of Compensation And Motivation To Spirit At Work Of Elementary School Teachers In Hulu Sungai Sub-District Of Ketapang Regency. JETL. Journal of Education, Teaching and Learning, 3(2).

Turin. L.O. (2002). Hubungan tingkat pendidikan, pengalaman penataran dan motivasi kerja dengan performansi mengajar guru-guru SMU negeri 3 Kendari Sulawesi Tenggara. Jurnal Pendidikan, 1(2).

Undang-Undang No. 14 tahun 2005 tentang Guru dan Dosen.

Undang-Undang No. 20 tahun 2003 tentang Sistem Pendidikan Nasional.

Widayati, K.D. (2019). Pengaruh Kompensasi Terhadap Kinerja Guru Pada Sekolah Dasar Negeri Jatiwaringin X Bekasi. Widya Cipta: Jurnal Sekretari dan Manajemen, $3(1)$.

Wijaya. (2000). Analisis statistik dengan program SPSS 10.0. Bandung: Alfabeta.

Winardi. (2001). Motivasi \& Pemotivasian dalam Manajemen. Jakarta: PT. Raja Grafindo Persada.

Yousaf, Usman, Usman, Bushra \& Islam, T. (2018). Effects of Supervision Practices of Principals on Work Performance and Growth of Primary School Teachers. Bulletin of Education and Research, 40(1).

Yuddin. (2017). Influence of the Compensation, motivation And Discipline work Against The work Achievement Teacher At SMA Negeri Jeneponto Regency west
Bangkala I.Quest Journals Journal of Research in Business and Management, 5(2): 83-88. 